\title{
CUADRO DE LA OFICINA DE LA PRESIDENCIA
}

\author{
Luis Alberto Blanco R. MD*
}

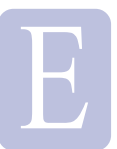

n las paredes de la sede de la presidencia de la Sociedad de Cirugía de Bogotá, Hospital de San José, se encuentra colgado un cuadro muy hermoso que representa el descendimiento de Cristo. La obra ejecutada y firmada por el gran pintor colombiano Epifanio Garay en la ciudad de París hacia 1885 , es en realidad una copia del original que el español José De Ribera pintó hacia finales de 1620 y se encuentra en la actualidad exhibida en el museo del Louvre en el Salón Denon, sección de pintura española, con el nombre La Déposition $d u$ Christ o Descendimiento de Cristo. El original pertenecía a la colección del cardenal Valentini Gonzaga y fue donado al museo en 1756.

\section{José De Ribera nació en Játiva, España, en 1591 y murió en Nápoles en 1652. Aunque español de naci- miento, realizó toda su obra en Italia influenciado por Caravaggio, es decir, fue amante de los "claroscu- ros" que son imá-}

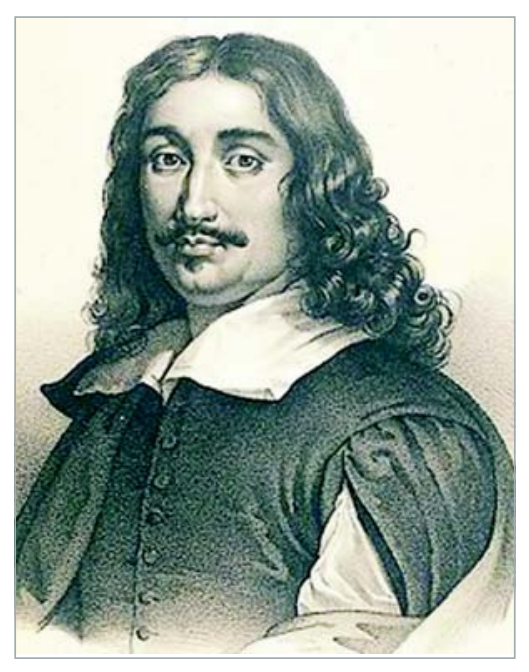
genes con una iluminación violenta, técnica comúnmente denominada en el arte de la pintura caravagismo, la cual es copiada y plasmada a la per- fección por Epifanio Garay en el cuadro que se encuentra en el hospital. Ribera, llamado en Italia "el Spanoletto" (el españolito) por su origen español, hizo pinturas famosas como El Patizambo, expuesta en el museo del Louvre, y la Mujer Barbuda, en Toledo.

\section{Epifanio Garay nació en Bogotá el 9 de enero de 1849 y murió en Villeta el 8 de octubre de 1903. Es, tal vez, el retra- tista académico más importante del arte colombiano. Siendo joven viajó a París y se matriculó en la academia Julien en donde hizo la copia}

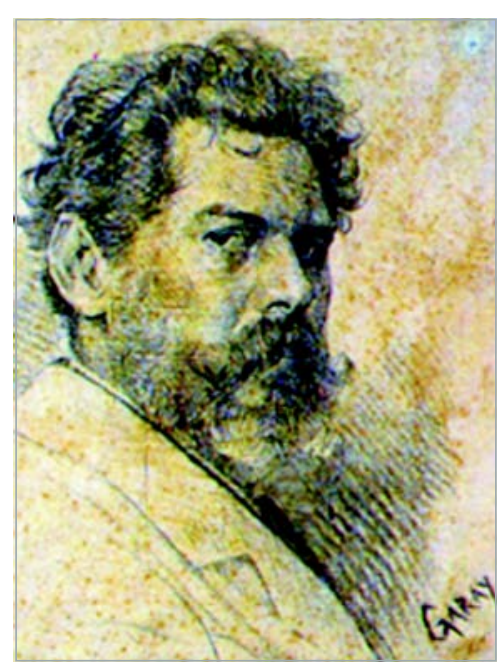
que se encuentra en el hospital. Tuvo contacto con Monet y fue cantante de ópera en el Music Hall de New York. Gran parte de su obra se encuentra en el Museo Nacional de Bogotá.

Dada la magnitud del museo del Louvre, el más grande de París y el tercero en el mundo, con más de 60.600 metros cuadrados útiles para exhibición, 380.000 objetos y 35.000 obras de arte, es emocionante descubrir el original de la bellísima copia que se encuentra en una oficina del Hospital de San José.

\footnotetext{
* Vicepresidente, Sociedad de Cirugía de Bogotá. Profesor Titular,
} Fundación Universitaria de Ciencias de la Salud, Bogotá DC, Colombia. 